\title{
„Ez a 'gender', ez már sajnos Magyarországot is fenyegeti” - nemisztereotípia-ellenes és/vagy nemileg differenciált nevelés koragyermekkorban
}

\author{
F. Lassú Zsuzsa \\ ELTE Tanító- és Óvóképző Kar, Neveléstudományi Tanszék
}

\begin{abstract}
A nem a legnyilvánvalóbb, legkiugróbb kategória az emberi csoportokról alkotott benyomások szerveződésében, ezáltal a sztereotípiaképzés legbiztosabb alapja is egyben. A nemi sztereotípiák megkülönböztetéshez, szexizmushoz, nemi diszkriminációhoz vezethetnek, így az ellenük való küzdelem a pedagógia egyik fontos célkitűzése lehet. Jelen tanulmány célja a nemröl való gondolkodás fejlődésének és a nemi sztereotípiák koragyermekkori kialakulásának, valamint a nemi egyenlöségért, a nemi sztereotípiák ellen küzdő ún. genderpedagógia koragyermekkori lehetőségeinek bemutatása, elsősorban svéd és amerikai oktatási programokon keresztül.
\end{abstract}

Kulcsszavak: nemekröl való gondolkodás, nemi sztereotípiák, svéd modell, nemileg szegregált oktatás, koragyermekkori nevelés

A nem a legnyilvánvalóbb, legkiugróbb kategória az emberi csoportokról alkotott benyomások szerveződésében. Már az egészen kis gyermekek is képesek az emberi arcokat nemileg elkülöníteni (Quinn et al., 2002), és különböző nemekhez kapcsolni bizonyos cselekvéseket, vagy eszközöket, foglalkozásokat (Fagot, Leinbach és O'Boyle, 1992; Poulin-Dubois, Serbin és Derbyshire, 1998). A nemi sztereotípiák, elöítéletek kialakulása, a nemi elkülönülés, a nemnek megfelelő viselkedés azonosítása, utánzása és a szabályszegéshez való viszony, mind a kognitív fejlődéssel párhuzamosan, annak részeként alakuló fejlődési folyamat (Id. Martin és Ruble, 2010). Mindezekből logikusan következik, hogy emberi társadalmunk megértése, a benne való eligazodás elképzelhetetlen a nemi kategóriák nélkül. Ugyanakkor ezek a kategóriák az alapjai a nemekhez mereven rendelt és túláltalánosított tulajdonságkészlet automatikus aktivizálódásának, a sztereotípiaképzésnek is. A nemi sztereotípiák megkülönböztetéshez, szexizmushoz, nemi diszkriminációhoz vezethetnek, így az ellenük való küzdelem a pedagógia egyik fontos célkitüzése lehet. Jelen tanulmány célja a nemről való gondolkodás fejlödésének és a nemi sztereotípiák koragyermekkori kialakulásának, valamint a nemi egyenlőségért, a nemi sztereotípiák ellen küzdő ún. genderpedagógia koragyermekkori lehetőségeinek bemutatása, elsősorban a svéd oktatási programokon keresztül.

\section{A nem megértése - nemi sztereotípiák, elöítéletek és diszkrimináció koragyermekkorban}

A nemekről való gondolkodás fejlődésének önszocializációs álláspontja szerint a gyermekek alapvető ismeretei saját nemi identitásukról motiválják és szervezik a nemileg megfelelő viselkedést, vagyis a gyermek aktívan keresi a nemiségre vonatkozó információkat, ezekből felépíti a nemiség konstrukcióját, mely szervezi és irányítja a nemnek megfelelő viselkedést (Martin et al., 2002). Ezzel ellentétben más kutatók azt hangsúlyozzák, hogy a gyermekek már jóval saját nemi identitásuk kialakulása előtt nemüknek megfelelően viselkednek pl. játékválasztásban, tevékenységpreferenciában (Campbell, Shirley és Caygill, 2002). A bevezetöben említett korai képességek a nemek megkülön- 
„Ez a 'gender', ez már sajnos Magyarországot is fenyegeti” ...

böztetésére arc vagy hang alapján (3-4 hónapos korban arcok megkülönböztetése, 6 hónaposan különböző nemü arcok és hangok egymáshoz rendelése), vagy egyszerü tárgyak különböző nemü arcokkal társítása (10 hónapos korban) tényleg megelőzi a saját nem azonosításának képességét, amelyet kísérleti körülmények között legkorábban 18 hónapos lányoknál tudtak azonosítani (Poulin-Dubois, Serbin és Derbyshire, 1998; Quinn et al., 2002). Természetesen a nemi kategóriák vizsgálatára vonatkozó csecsemőkori kutatások eredményeinek értelmezése csak nagy körültekintéssel történhet. $A$ beszéd és az ezzel párhuzamosan fejlődő aktív cselekvés képességének egyre magasabb szintjével a kutatás lehetőségei kitágulnak. Zosuls és munkatársai (2009) eredményei szerint a lányok átlagosan 18 hónapos korukban már nemi címkékkel látják el a nemileg tipikus játékokat (autók, babák), és azok, akik a leggyakrabban címkézik ezeket a játékokat, valószínübben játszanak velük nemileg tipikus módon. A kutatások alapján azt mondhatjuk, hogy a gyermekek kb. 18-24 hónapos korukra képesek megnevezni a nemeket, és a nemi kategóriákat beszédükben, spontán játékhelyzetben is használni. Mindezt elősegíti a nemileg megfelelő játékokkal való gyakori játék.

Az egyes nemekhez kapcsolt tulajdonság- és tevékenységkészlet, azaz a nemi sztereotípiák is viszonylag hamar kialakulnak a gyermekekben. Kezdetleges formában már a kétévesek is sztereotipizálnak, és sok gyermek 3 évesen rendelkezik a nemi sztereotípiák alapvető tartalmáról való tudással (Signorella, Bigler és Liben, 1993). Verbalitást nélkülöző, ún. nézéspreferencia-módszert alkalmazó kutatásban a gyermekek már két éves koruk előtt képesek az egyes nemekhez közvetlenül (használat útján) vagy metaforikusan tartozó tárgyakat azonosítani (Eichstedt, Serbin, Poulin-Dubois és Sen, 2002). A tárgyi világ után az elvont tulajdonságok odaítélése is megkezdődik a harmadik életévben. Kutatások eredményei szerint 3-5 éves kortól kezdődően a legtöbb gyermek nemek szerint osztja a tulajdonságokat: a lányok kedvesek, a fiúk vadak (Miller et al., 2009), sőt a 4-5 évesek már azt is tudják, hogy a lányok inkább kapcsolati agressziót használnak, míg a fiúk inkább fizikait (Giles és Heyman, 2005). A sztereotípiák tartalma az életkorral gazdagodik, a sztereotípia-merevség kb. 5-6 éves korban éri el csúcsát, majd 8 éves kor körül növekszik a rugalmasság (Trautner et al., 2005).

A nemi kategóriákban való gondolkodás automatikusan előidézi a saját csoport felértékelését ${ }^{1}$, az ún. ingoup biast (Ruble et al., 2004). Az óvodás korban megjelenő saját nempreferencia iskolás korban a sztereotípiák rugalmasságának növekedésével csökken, bár visszatekintve gyermekkorunkra felnőttként is hajlamosak vagyunk a fiúkat „hülyéknek”, a lányokat „majmoknak” címkézni (Id. F. Lassú, 2015), főként ha a nemi kategória egy helyzetben kiemelődik, hangsúlyossá válik. Az, hogy a saját csoport felértékelése mennyiben és mikortól jár együtt a másik csoport leértékelésével, még nem megválaszolható a kutatások által. Ugyan vannak arra vonatkozó eredmények, hogy a gyermekek igen korán értékelően viszonyulnak egymáshoz, azonban ezek talán másként is értelmezhetők, mint ellenségesség (Kowalski, 2007). Nem világos például, hogy a lányok fiúkról alkotott ítélete, miszerint „rosszak”, nyílt ellenségesség, vagy csak azt a sztereotípiát tükrözi, hogy a fiúk gyakran okoznak a felnőtteknek gondot, keverednek „rosszaságba” (Heyman, 2001; Kalcsó és F. Lassú, 2016).

A következő felmerülő kérdés az előítéletes, szexista gondolkodás megjelenése gyermekkorban. Valamely nemmel, elsősorban a nőkkel szembeni negatív megkülönböztetés ölthet ellenséges vagy jóindulatú formát, illetve ezek kombinációjaként létrejöhet az

\footnotetext{
1 Ugyan a nemi sztereotípiák esetén beszélhetünk a saját csoport leértékeléséről is a nők részéről, azonosulva a kultúrában osztott sztereotípiákkal, ez azonban gyermekkorban még nem jellemző (Id. Powlishta, 1995).
} 
ún. ambivalens szexizmus is (Glick és Fiske, 2001). A jóindulatú szexizmus a nők nyílt becsmérlése helyett azok védtelen és gyenge természetét hangsúlyozza, miáltal védelemre, támogatásra szorulnak - ezáltal igazolva a paternalisztikus patriarchátus gyakorlatát a nők háztartásba, gyermeknevelésbe és vallásgyakorlásba való korlátozására (Kinder, Küche, Kirche). A kutatások szerint koragyermekkorban nem jellemző a szexista gondolkodás, és később is problémát jelent az ambivalencia értelmezése, így a gyermekek csak lassan fordulnak át az ellenkező nemüekkel szembeni nyílt ellenségességből az ambivalens szexizmus felé (Rudman és Glick, 2008). Lehetséges azonban a kérdést másként is megközelíteni. A gyermekek ellenkező nemüek iránti leértékelése egyrészt nem feltétlenül ellenséges szándékú, csak tükrözi a korlátozott kognitív kapacitás hiányában megtett fontos kategorikus distinkció elégtelenségét (Kowalski, 2007). Másrészt a gyermekek másneműek irányában mutatott értékelő megnyilvánulásai tartalmukban sem egységesen ellenségesek, hanem ambivalenciát mutatnak, azonban nem a felnőtt ambivalens szexizmus értelmében. A másneműekről gyermekkorban alkotott vélekedések sokszor sokkal árnyaltabbak, mint a felnőtteké, amennyiben fiúk és lányok értékelik egymásban a belölük hiányzónak ítélt, vagy nem elég fejlett képességeket (Id. F. Lassú, 2015).

A kép tehát korántsem tiszta és gyermekkorban korántsem olyan rémisztő, mint felnőttkorban. Ahhoz azonban, hogy csökkentsük a későbbi szexista, sztereotip gondolkodás és viszonyulás kialakulásának valószínüségét, pedagógiai beavatkozásokra is szükség van.

\section{Svédország irányelvei a nemi egyenlőség oktatáspolitikájában}

Svédország a skandináv országok viszonylatában is úttörőnek számít a koragyermekkori nevelés terén megvalósuló, nemi sztereotípiák és diszkrimináció elleni harcban, valamint a nemi nevelés terén (Bayne, 2009; Sherlock, 2012). A hatvanas években világszerte megújuló nemek közötti egyenlőségről folyó diskurzus eredményeként már az 1962-ben létrejövő 9 évfolyamos általános iskolák első tantervében hangsúlyozott a nemi egyenlőség kérdésköre, és az 1969-ben kiadott második tanterv már célzottan a nemi szerepek megváltoztatására irányul (Bayne, 2009). Az iskoláskor előtti oktatás és nevelés (nálunk: bölcsődék és óvodák) a '80-as évek végétől szintén az egyenlöség elvét hangsúlyozza, annak aktív támogatását tüzi célul (National Board of Health and Welfare 1987, 3. o., idézi Ärlemalm-Hagsér, 2010). Az óvoda azonban csak 1998ban válik a közoktatás részévé, amikortól számukra is elkészül egy átfogó tanterv. Az ekkor kiadott óvodai tanterv egyértelmú célja a nemi sztereotípiák elleni harc:

„Ahogyan a felnőttek a fiúkra és lányokra reagálnak, amilyen elvárásokkal velük szemben fellépnek, befolyásolja a fiúk és lányok megértését azzal kapcsolatban, mi számít férfiasnak és mi nőiesnek. Az óvodáknak ellensúlyozniuk kell a hagyományos nemi mintákat és nemi szerepeket. Fiúknak és lányoknak az óvodában egyenlö lehetőséget kell biztosítani, hogy kipróbálják és fejlesszék képességeiket és érdeklödésüket a nemi sztereotípiák korlátai nélkül." (Ministry of Education and Science, 2006, 4. idézi Bayne, 2009, 131. o.)

Az alapelvek gyakorlati megvalósítását Svédország-szerte számos pedagógiai projekt támogatta (Bayne, 2009), melyek hatását az óvodába járó gyermekek kb. 15\%-a közvetlenül tapasztalhatta. A pedagógiai programok bevezetése, lebonyolítása és ér- 
tékelése jól dokumentált volt, ún. research study circles ${ }^{2}$, vagyis az adott fejlesztésre szerveződött rendszeres kutatói megbeszélések keretében bonyolódott, több kísérleti program eredményét könyvekben, tanulmányokban publikálták (Bayne, 2009). A projektek dokumentálásának egyik leggyakoribb módja a gyermekek és pedagógusaik interakciójának filmre rögzítése és elemzése volt. Ennek eredményeként számos esetben derült fény a pedagógus által nem is tudatosuló sztereotip bánásmódra, fiúk és lányok viselkedésének eltérő értelmezésére, és az azokra való nemileg meghatározott reakciókra. Ezek közül egyet érdekességként emelek ki. A rögzített interakciók elemzése szerint a pedagógusok sokkal gyorsabban reagálnak a fiúk igényeire, mint a lányokéira, azokat sürgetőbbnek élik meg. Ez olyan meghatározó vonása a koragyermekkori nevelésnek, hogy nevet is kapott, „boy panic” (svédül pojkpanik), magyarul talán a „fiú frász” kifejezés áll a legközelebb a jelenséghez (Bayne, 2009, 133. o.). A „fiú frász”-ra való azonnali reakcióval a pedagógusok megerősítik a gyermekekben a patriarchális társadalmi berendezkedést, amelyben a férfiaknak hatalma van, a nők csak másodikak lehetnek a sorban, miután a férfiak igénye kielégült (vö. evolúciós pszichológiai nézőpont: a hím oroszlán elsősége a préda elfogyasztásában).

\section{A nemi egyenlőséget támogató leggyakoribb módszerek}

Az egyik leginkább elterjedt megközelítés a kompenzatorikus pedagógia, amely a dán Anne Mette Kruse pedagógiai koncepciójából származik (Bayne, 2009). A kompenzatorikus pedagógia abból a nézetből indul ki, hogy a fiúkat általában önállónak neveljük, míg a lányok nevelése során a másokhoz való közelséget értékeljük és erősítjük meg (vö. kapcsolati és autonóm selfelmélet - Miller, 1976). A genderpedagógia célja ezért a gyermekek támogatása az általuk kevésbé gyakorolt, a társadalom által nemüknek „nem megfelelő” tevékenységekben - a fiúk empátiájának, kapcsolati képességeinek és a lányok önállóságának, bátorságának fejlesztése. Ennek érdekében néhány óvoda egynemủ tevékenységeket szervez, így elősegítve a gyermekek komfortérzetét. Az egynemű óvodai közeg használata az ún. Hjalli-pedagógia ötlete, melyet az izlandi Margret Pála Ólafsdóttir fejlesztett ki (Ólafsdóttir, 1996; Bayne, 2009). Az egynemü közegben végzett tevékenységek, pl. az étkezés során a fiúkat a segítőkészségre, mások figyelembe vételére, a szabályok betartására stb. ösztönzik, míg a lányokat arra, hogyan tudatosítsák és fejezzék ki igényeiket, értékeljék önmagukat pozitívan stb. (Wahlström, 2004, idézi Bayne, 2009). Az egynemü oktatás számos kritikát kapott, melyeket lentebb az amerikai példáknál részletezünk.

Egy másik, szintén radikálisnak tűnő gyakorlat a nemileg specifikus játékok (babák, autók, fegyverek) és nemileg sztereotip mesekönyvek eltávolítása a csoportszobából, és nemileg semleges játékokkal (puzzle, kreatív és építő játékok) való helyettesítésük. Talán ez az a gyakorlat, amely a magyar sajtóban a legnagyobb felháborodást kiváltotta, ahogyan ezt az Eduline-on ${ }^{3}$ megjelent cikkre adott hozzászólásokból is láthatjuk:

„Ez egy aljas, liberális, emberellenes kísérlet, mert csak az embert lehet őrült, aberrált, ferdehajlamú viselkedésre, szokásokra rávenni. Ez az emberi nem elkorcsosulásához vezet. Szerencsére az állatokra ekkora baromságot nem lehet rátukmálni. Így legalább az állatvilág fennmaradásában bízhatunk, mert az állatokra nem lehet hatni észérvekkel, mert ösztönlények."

\footnotetext{
2 a study circle módszer leírását Id. Larsson (2001), részletesen: http://www.academia.edu/360012/Study_ circles_and_Democracy_in_Sweden

${ }^{3}$ http://eduline.hu/kozoktatas/2011/7/3/20110703_ovoda_nemi_sztereotipia
} 
A fentinél kevésbé radikális módszer a csoportszobai terek forgószínpadszerü használatának támogatása, melynek eredményeként minden gyermek, nemétől függetlenül részt vehet minden tevékenységben. Ennek monitorozása azonban a módszer sikerének kulcsa, e nélkül a gyerekek újból nemüknek megfelelően, sztereotip módon kezdenek játszani.

Szintén bevett gyakorlat a svéd óvodákban az érdekes foglalkozású szülök meghívása, amely a genderpedagógia céljainak megfelelően alakítva nemileg „nem megfelelő” foglalkozású szülőt, pl. női pilótát, vagy férfi óvodapedagógust (!) jelenthet. Ezen a vonalon továbbmenve, a sztereotípiák lebontását segítheti az anti-sztereotip mesék, történetek olvasása is (legjobb példa erre a szintén svéd Harisnyás Pippi).

További, a genderpedagógiát támogató gyakorlat lehet a férfiak arányának növelése a koragyermekkori nevelés területén. Svédországban, csakúgy, mint Skandinávia más országaiban világviszonylatban, de európai viszonylatban is nagyobb arányban vesznek részt férfiak a korai nevelési intézmények munkájában. Míg Magyarországon kb. 7-10 aktívan óvodapedagógusként dolgozó férfi pedagógusról tudunk, addig Svédországban az óvodapedagógusok 6\%-a férfi. A férfijelenlét pedagógiai előnyeit számos kutatásban vizsgálták, az eredmények azonban ellentmondóak (Id. Cushman, 2010). A vizsgálatok ugyanakkor föleg a tanárokra vonatkoztak, kevés kutatás irányul a férfiak óvodai jelenlétére. A skandináv kutatások eredményei, Penni Cushman kutatásaihoz hasonlóan, ellentmondóak, mivel a férfiak „férfias” szerepét, vadabb játéktevékenységét, vagy erejét emelik ki (Sandberg és Pramling-Samuelsson, 2005), megerősítve ezzel a nemi sztereotípiákat (vö. Kalcsó és F. Lassú eredményeit jelen folyóiratszámban). Vitathatatlan azonban a férfiak koragyermekkori nevelésben betöltött szerepének az az előnye, hogy oldja a nevelés női területként értelmezett jellegét, ezáltal a női gondoskodás egyeduralmának félelmetességét (vö. feminista klasszikusok pl. Dinnerstein, Chodorow, Kristeva az anyaságról - Kende, 2005). Érdemes ugyanakkor azzal az előítéletes gondolkodással is foglalkozni, amely a koragyermekkori nevelésben professzionálisan részt vevő férfiakat femininnek, vagy homoszexuálisnak minősíti, magát a heteroszexuálistól eltérő szexuális orientációt pedig a pedagóguspályára való alkalmasságot kizáró tényezőnek tartja (Robinson, 2002). Mindezek jelzik, hogy a nemi diverzitás kérdésköre nagyon megosztó terület, számos eltérő nézőpont bukkan fel tárgyalásakor, melyeket érdemes a nemi egyenlőséget célzó programok tervezésekor figyelembe venni (Jacobson, 2016).

A genderprojektek lassan éreztetik hatásukat a gyakorlatban, és a svéd szakemberek a mai napig is elégedetlenek az eredményekkel. Az óvodai mindennapok gyakorlatát és a pedagógusok hozzáállását vizsgálva számos kutatás elvileg elismert, de praktikusan problémákba ütköző nézőpontnak találta a nemi egyenlőség elvét. Nemileg meghatározottnak találták a szabadtéri játékok használatát (Ärlemalm-Hagsér, 2010) csakúgy, mint a vezetett foglalkozásokat, a csoportszoba térbeli használatát, valamint a gyermeki viselkedésre adott pedagógusi reakciókat (Emilson és Johansson, 2013). Mindezek az eredmények szoros összefüggést mutatnak az évtizedek óta következetesen igazolt elmélettel, az azonos nemü társak választásának preferenciájával (Maccoby és Jacklin, 1987), mely nemileg szegregált játéktevékenységekhez vezet az óvodákban (Martin et al., 2013), és az iskolákban, majd nemileg elkülönülő barátok preferenciáját eredményezi serdülőkorban (Updegraff, McHale és Crouter, 2000).

\section{A nemileg differenciált nevelés gondolata}

A természetesen megjelenő nemi szegregációt hangsúlyozzák az egynemü közoktatást támogató iskolák pedagógusai és a mögöttük álló kutatók. Azelsősorban Leonard Saxés 
David Gurian munkásságára épülő mozgalom alapelve, hogy a fiúk és lányok agyában genetikailag kódolt strukturális és funkcionális eltérések (ld. Cosgrove, Mazure és Staley, 2007) olyan pszichológiai különbségekhez vezetnek, melyek akár már óvodás korban, de az iskolában mindenképp szükségessé teszik a nemileg differenciált oktatást és nevelést (Sax, 2006; Gurian és Stevens, 2005). A nemileg differenciált nevelés átgondolt bevezetése ugyan nem jelent(het) hátrányos megkülönböztetést egyik nem számára sem, sőt éppen a tradicionális gyakorlatban jelen lévő, sztereotípiákra épülő megkülönbözetést célozza megszüntetni, azonban számos kritikával illették az elgondolás nyomán megindult nemi szegregációt. Ezek közül kiemelkedő a nemi sztereotípiákat megerősítő, vagy a társas fejlődést hátráltató hatások hangsúlyozása (Novotney, 2011). Természetesen a kritikákra az egynemü nevelés elkötelezett híveinek is megvan a válaszuk, és a vita, ha tudományos nézőpontokon és tényeken alapul, mindenképpen segíti a kérdés árnyaltabb megértését.

Az amerikai nemileg szegregált oktatás népszerüsége 2001 után növekedett meg, amikor a „No Child Left Behind Act”4, vagyis a hátrányos helyzetü gyermekek egyenlő oktatási esélyeit garantáló törvény életbe lépett, és amely lehetővé tette az oktatási intézményeknek, hogy innovatív programokat vezessenek be, akár egynemű iskolákat hozzanak létre, igazodva a helyi szabályozókhoz. Jelenleg 100 körüli az egynemú államilag fenntartott iskolák száma, és több mint 400 koedukált állami iskola szervez egynemű osztályokat. Az egynemű oktatás alapgondolata szerint az eltérő pszichológiai és biológiai sajátosságok és az ezáltali eltérő tanulási képességek, stílus, motiváció stb. által teremtett differenciáló pedagógiai módszertani igények könnyebben megvalósíthatók egynemủ csoportokban. A nemileg szegregált oktatás természetesen föleg a középiskolákban sikeres, ahol tudatosan próbálják ezáltal kompenzálni a kétnemüségben rejlő vonzások, megfelelni vágyás, megalázástól való félelem tanulást hátráltató hatásait (Sax, 2006). A lányok bátrabban vágnak bele a tudomány világának megismerésébe vagy a sportba, a fiúk pedig kevésbé tartják lányosnak a művészeti tevékenységeket, a drámát és az olvasást (Norfleet, James és Richards, 2003) - éppen úgy, ahogyan azt a svéd óvodaisztereotípia-ellenes projektek eredményeként célozták elérni. Más kutatók azonban éppen a nemi sztereotípiák erősödésétől tartanak a nemi szegregáció hatására, valamint attól, hogy a társadalmi valóságtól eltérő tapasztalatok nem segítik a fiatalokat a nemek közötti együttműködésben. Hilliard és Liben (2010) óvodás gyermekek között végzett vizsgálatai szerint a nemileg elkülönülten szervezett tevékenységek növelték a nemi sztereotípiák erősségét a gyermekek között - ugyanakkor ebben a kutatásban a nemi szegregáció a csoporton belül, a másik nem jelenlétében történt, ami eltérő a nemileg szegregált oktatás gyakorlatától, és érthető módon kelti a gyermekekben a diszkrimináció érzetét.

Noha a szegregált oktatás hatásait vizsgáló kutatások meglehetősen összetett és ellentmondó eredményeket hoztak, a megfelelő módon bevezetett és szakmailag megalapozott egynemủ oktatás sok fiatal számára vonzó alternatíva lehet a koedukációval szemben (Novotney, 2011). Az azonban az eddigi áttekintésből is egyértelmű, hogy további, minden álláspontot tudományos módszerekkel vizsgáló kutatásokra van szükség a témában.

\footnotetext{
${ }^{4}$ http://www2.ed.gov/policy/elsec/leg/esea02/index.html
} 


\section{A magyar szabályozás az óvodai nevelés társadalmi nemi vonatkozásairól - avagy a „gender” sajnos Magyarországot nem fenyegeti}

A hagyományos heteroszexista és patriarchális berendezkedés lényegében sem a politikában sem a társadalom egyéb intézményeiben nem változott a rendszerváltást követően (Ilonszki, 2014). Az 1993-as közoktatási törvény 1996-ban kiadott mellékleteként létrejött Óvodai Nevelés Országos Alapprogramja (ÓNOAP), bár sok tekintetben reformként értelmezhető, egyetlen szóval sem említi a nemi nevelés, nemi egyenlőség kérdésköreit. Egyetlen utalás történik a bevezetésben „az emberi jogok és alapvető szabadságok tiszteletben tartására”, valamint az óvodai nevelés feladatairól szóló részben a „másság elfogadására". Az akkori liberális oktatáspolitika ugyanakkor időnként, némileg előkészítetlenül és összehangolatlanul, olyan kezdeményezéseknek is teret adott, amely a nemi egyenlöség korai megalapozását célozta. llyen volt az ÓNOAP 2009 évi módosítása.

A 255/2009. (XI. 20.) Kormányrendelet az Óvodai Nevelés Országos Alapprogramjáról a 2. sz. melléklet 2. bekezdésében, az alábbi szövegrészben említi a nemi szerepek és sztereotípiák kérdéskörét: „Az óvodai nevelés gyermekközpontú, befogadó, ennek megfelelöen a gyermeki személyiség kibontakoztatására törekszik, biztositva minden gyermek számára az egyenlö hozzáférést, tudatosan kerüli a nemi sztereotípiák erösítését, elősegíti a nemek társadalmi egyenlőségével kapcsolatos elöítéletek lebontását."

A kibontakozó társadalmi diskurzus, többségében felháborodott szülök és pedagógusok véleménye alapján, egy nemek nélküli óvoda képét vizionálta, mely a döntően keresztény Magyarországon a család halálát jelentené. Az érvek elsősorban a nemi szerepek helyénvalóságát, a családi munkamegosztás évezredes és jól funkcionáló voltát hangsúlyozták, melyet megbontva férfiak és nők nem tudnának harmonikusan családban élni, ezáltal gyermeket nevelni, sőt a gyermeknemzés és veszélybe kerülne. A Katolikus Pedagógiai Szervezési és Továbbképző Intézet tájékoztatást kért az akkori Oktatási és Kulturális Minisztérium szakállamtitkárától, aki az alábbiak szerint próbálta megnyugtatni a pedagógusokat (a szövegböl célzottan kiragadtam a megnyugtatónak szánt, ugyanakkor genderszempontból továbbra is vitatható részeket):

„...az Alapprogramban található mondat a nemi sztereotípiákkal kapcsolatban nem jelentheti azt - a legnagyobb félremagyarázás mellett sem -, hogy az óvodának feladata a nemi szerepek eltakarása, a nemi identitás megszüntetése. ... óvodai nevelésnek a gyermeki személyiség teljes kibontakoztatására kell irányulnia. Ez értelemszerüen magába kell, hogy foglalja a nemi szerepekröl történó gondolkodást is. ... Nem vitatható az óvodában sem, hogy más a szerepe a családban a nónek, az anyának és más a szerepe a férfinak, a férjnek. ...Meg szeretném Önt nyugtatni továbbá, hogy a népmesék, a magyar gyermekköltészet, a népi hagyományok, a mindennapos mondókázások, verselések, szólások, közmondások, ..., jó alapot kínálnak a ... a nemi szerepek megismertetésére, a családról kialakításra kerülő kép egészséges (SIC!) irányba történő formálására."

Mindenképpen elgondolkodtató, hogy az államtitkár a hagyományos nemi szerepek védelmében, azokat propagálva érvel, a hagyományos családi munkamegosztás fenntartása mellett áll ki, melyeket szerinte a módosítás nem célzott megváltoztatni. A nem hivatalos kommunikáció azonban a szülőknek szóló site-okon is megindult, némelyek ezek közül szakértőt kértek fel a téma értelmezésére. Így olvashatjuk mai napig a babafalva.hu egy tárolt oldalán ${ }^{5}$ Juhász Borbála, a Magyar Női Érdekérvényesítő Szövetség vezetője szakmailag megalapozott hozzászólását a témához. A téma „izgalmasságát” jelzi, hogy

\footnotetext{
${ }^{5}$ http://babafalva.hu/vitak-es-felreertesek-az-uj-ovodai-alapprogram-korul/
} 
mindössze két szülői hozzászólás érkezett, az egyik a konzervatív oldalról („Mondhat akárki akármit, a kisfiú legyen kisfiú, a kislány meg kislány. A nemi szerepek keveredése miatt van olyan sok férfias nö, és nőies férfi, és lassan már azt se tudják az emberkék, hogy kicsodák a nagy "szabadságban"), a másik viszont éppen az elfogadást hangsúlyozó táborból („Érdekes, hogy az ehhez hasonló lehetőséget, választást biztosító és nem tiltó módosítások miért keltenek sokakban félelmet vagy bizonytalanságérzetet. Senki nem gondolhatja komolyan, hogy egy kisfiúból azért nem lesz IGAZI FÉRFI (milyen is az?) (neaggyisten meleg), mert 5 évesen föz a babakonyhában, esetleg kedveli a rózsaszínt."). A felmerült nézőpontok elemzése akár egy önálló kutatás témája is lehetne, hiszen az identitás kérdésének a szabadsághoz, a meghatározottsághoz, a normáknak való megfeleléshez kapcsolódósát tárja a pszichológiai vizsgálat témájaként elénk.

A 2010. évi kormányváltással bekövetkező újbóli konzervatív fordulat teret adott a közbeszédben erős ellenérzéseknek, újból módosítva az Alapprogramot. Az akkori Nemzeti Erőforrás Minisztérium 2010. augusztus 10-i közleményében ${ }^{6}$ az alábbiakkal indokolja a változtatás szükségességét:

„Az Óvodai nevelés országos alapprogramjának átfogó módosítására tavaly a 255/2009. (XI. 20.) Kormányrendeletben került sor. A rendelet korszerü, igényes óvodai alapprogramot határozott meg, azonban a szakmai és társadalmi egyeztetések lezárása után, az akkori kormány kezdeményezésére két olyan kiegészítéssel lépett hatályba, amelyek nem kerültek már vissza az egyébként kötelezö szakmai, társadalmi egyeztetésre, és azok a hatálybalépést követően jelentős társadalmi ellenérzéseket váltottak ki. A módosítás ezen két eleme vitatható irányba befolyásolta volna a gyermekek erkölcsi, szellemi fejlödését (SIC!), ezért a társadalmi ellenérzéseket kiváltott szövegrészletek vonatkozásában a szükséges és azonnali korrekciót az Oktatási Államtitkárság előkészítette és a Kormány 2010. júliusában jóváhagyta. A jelen Kormány 2010. júliusi döntése értelmében az Alapprogram szövegéből kikerült a nemi sztereotípiák erősítésének tudatos kerülése, és e mondata úgy változott meg, hogy az óvoda "nem ad helyet az elöitéletek kibontakozásának sem társadalmi, sem nemi, sem egyéb értelemben."

Az idézetben említett vitatható erkölcsi fejlődési irány erős utalás a merev nemi szerepek és sztereotípiák ellen harcoló lobbi meleg-jogi aktivitására, arra az összefüggésre, amely nem csak feltételezetten, hanem céljaiban, alapleveiben és szakértőinek személyeiben ténylegesen is összeköti a nemi egyenlőségért harcoló feminista és a diszkriminációellenes meleg-jogi mozgalmakat. A 2006-os választási kampányban megidézett szingli hordák ${ }^{7}$ rémétől félő politikusok a jól körülírt nemi szerepekben látták a család egységét, amely megvéd bennünket az erkölcsi fertőtől. $A$ „gender mainstreaming" ugyanakkor nem ezt célozza, nem a nemek összemosását, hanem a nemi esélyegyenlőség növelését, mely nélkül a sokat emlegetett „gender gap” vagyis a nemek közötti szakadék nem fog csökkeni, sem az oktatás, sem a foglalkoztatás statisztikáiban (Rédai, 2010; Kereszty, 2014).

\section{Összegzés}

Tanulmányunkban áttekintettük a nemileg érzékeny nevelés legmeghatározóbb skandináv vonulatát, az ún. svéd modellt, amelynek kapcsán bemutattuk a nemi esélyegyenlőséget célzó koragyermekkori programok legfontosabb elemeit; valamint az

\footnotetext{
${ }^{6}$ http://www.nefmi.gov.hu/2010/modosult-ovodai-neveles

7 http://index.hu/belfold/mikola060325/
} 
észek-amerikai nemileg szegregált oktatás alapelveit. Áttekintésünk természetesen több okból sem lehet teljeskörü. Skandinávia nem egységes pedagógiai gyakorlatában és nézőpontjaiban, így érdemes lenne összegyűjteni más északi országok nemi diszkrimináció elleni közoktatási törekvéseit és szabályozásait, és összevetni egymással, illetve más kultúrájú, például dél-európai országok szabályozásával és gyakorlatával. A nemileg szegregált oktatásnak is sokféle formája ismert, az oktatás szintjétöl és a szegregáció fokától függően, ezért ezek a programok egymással nehezen összevethetők, eredményességük tudományosan kevéssé vizsgált, így jövőbeli kutatások témája lehet.

Magyarország bizonyos vonatkozásaiban emancipáltnak tekinthető, tradícióit és a jelenlegi közmegegyezést tekintve azonban komoly lemaradásaink vannak a skandinávokkal szemben a nemi nevelés és nemi egyenlőség tekintetében. A hagyományos nemi szerepekhez való ragaszkodás egyfajta status quo-t jelent, amelyet hazánkban (iskolázottságtól és ideológiáktól függő mértékben) az emberek többsége oszt. Így szoktuk, ezt ismerjük, ez müködni látszik. Hogy mennyire nem müködik, vagy diszfunkcionális a hagyományosan működő családok többsége, azt a gyermek- és családvédelemben dolgozók látják közelröl.

A merev határokkal és szerepekkel rendelkező rendszer definíció szerint nem lehet rugalmas, és így a környezeti változásokra való reagálása is rosszabb. A rugalmatlan rendszerek hajlamosak a túlterhelödésre, feszültségekre, törésre és robbanásra. A családon beüli erőszak magas száma, és arányaiban magas eltitkoltsága a rendszer diszfunkcionális működését jelzi. Hasonlóképpen problémákat észlelhetünk a munkahelyeken, ahol az alkalmazás, bérek és előrejutás nemi meghatározottságát láthatjuk. Mindezek a nemekről való patriarchális gondolkodás és berendezkedés következményei. Pedagógiailag számos módszerrel segíthetjük a nemek egyenrangúságát, a nemi sztereotípiák elleni küzdelmet, és ha nincs is erre országos mozgalom, egyéni eltökéltségünk a helyi közösségben változásokat eredményezhet.

\section{Felhasznált irodalom}

Ärlemalm-Hagsér, E. (2010): Gender choreography and micro-structures - early childhood professionals' understanding of gender roles and gender patterns in outdoor play and learning. European Early Childhood Education Research Journal, 18. 4. sz., 515-525.

Bayne, E. (2009): Gender pedagogy in Swedish pre-schools: An overview. Gender Issues, 26. 2. sz., 130-140.

Campbell, A., Shirley, L. és Caygill, L. (2002): Sex-typed preferences in three domains: Do two-year-olds need cognitive variables? British Journal of Psychology, 93. 2. sz., 203-217.

Cosgrove, K. P., Mazure, C. M., és Staley, J. K. (2007): Evolving Knowledge of Sex Differences in Brain Structure, Function and Chemistry. Biological Psychiatry, 62. 8. sz., 847-855.

Cushman, P. (2010): Male primary school teachers: Helping or hindering a move to gender equity? Teaching and Teacher Education, 26. 5. sz., 1211-1218.

Eichstedt, J. A., Serbin, L. A, Poulin-Dubois, D. és Sen, M. G. (2002): Of bears and men: Infants' knowledge of conventional and metaphorical gender stereotypes. Infant Behavior and Development. 25. 3. sz., 296-310.

Emilson, A. és Johansson, E. (2013): Participation and gender in circle-time situations in pre-school. International Journal of Early Years Education, 21. 1. sz., 56-69.

F. Lassú Zsuzsa (2015): „Természetesen a fiúk hülyék voltak” - kisiskoláskori baráti kapcsolatok fiatal felnőtt nők visszaemlékezéseinek tükrében. Gyermeknevelés, 3. 1. sz., 1-17.

Fagot, B. I., Leinbach, M. D. és O'Boyle, C. (1992): Gender labeling, gender stereotyping, and parenting behaviors. Developmental Psychology, 28. 2. sz., 225-230.

Giles, J. W. és Heyman, G. D. (2005): Young Children's Beliefs About the Relationship Between Gender and Aggressive Behavior. Child Development, 76. 1. sz., 107-121. 
Glick, P és Fiske, S. T. (2001): Ambivalent sexism. In: Zanna, M.P. (ed.): Advances in Experimental Social Psychology. Academic, Thousand Oaks, CA., 115-188.

Gurian, M. és Stevens, K. (2005): The Minds of Boys: Saving Our Sons From Falling Behind in School and Life. Jossey-Bass, San Francisco.

Heyman, G. D. (2001): Children's interpretation of ambiguous behavior: evidence for a "boys are bad" bias. Social Development, 10. 2. sz., 230-247.

Hilliard, L. J. és Liben, L. S. (2010): Differing Levels of Gender Salience in Preschool Classrooms: Effects on Children's Gender Attitudes and Intergroup Bias. Child Development, 81. 6. sz., 1787-1798.

Ilonszki Gabriella (2014): Jó kormányzás és a nemek egyenlősége. Magyarországi helyzetjelentés. In: Juhász Borbála (szerk.) A nőtlen évek ára. A nők helyzetének közpolitikai elemzése 1989-2013. Magyar Női Érdekérvényesítő Szövetség, Budapest, 29-58.

URL: http://noierdek.miria.hu/wp-content/uploads/2014/03/notlen-evek1.pdf

Jacobson, T. (2016): Gender diversity (szócikk) In: Donna Couchenour és J. Kent Chrisman (Eds.): The SAGE Encyclopedia of Contemporary Early Childhood Education. Volume 1. SAGE Publications, Thousand Oaks, California, 621-623.

Kalcsó Réka és F. Lassú Zsuzsa (2016): Óvodás gyermekek nemi sztereotípiáinak vizsgálata a pedagógus nemével összefüggésben. Gyermeknevelés, 4. 3. sz., 32-47.

Kende Anna (2005): Anyaság a pszichoanalízisben. Lehetséges következtetések a nő mint szubjektum szemszögéböl. Thalassa, 16., 1. sz., 63-82. URL: http://www.mtapi.hu/ thalassa/a_folyoirat/e_szovegek/pdf/(16)2005_1/063-82_Kende-A.pdf

Kereszty Orsolya (2014): Nők az oktatásban Magyarországon. In: Juhász Borbála (szerk.) A nőtlen évek ára. A nők helyzetének közpolitikai elemzése 1989-2013. Magyar Női Érdekérvényesítő Szövetség, Budapest, 259-294.

URL: http://noierdek.miria.hu/wp-content/uploads/2014/03/notlen-evek1.pdf

Kowalski, K. (2007): The development of social identity and intergroup attitudes in young children. In: Saracho, O. N. és Spodek, B. (eds.): Contemporary Perspectives on Social Learning in Early Childhood Education. Information Age Publishing, Charlotte, NC, 51-84.

Larsson, S. (2001): Seven aspects of democracy as related to study circles. International Journal of Lifelong Education, 20. 3. sz., 199-217.

Maccoby, E. E. és Jacklin, C. N. (1987): Gender segregation in childhood. In: Hayne, W.R. (ed): Advances in child development and behavior. Vol. 20. Academic Press, Inc., Orlando, FL, US, 239-287.

Martin, C. L., és Ruble, D. N. (2010): Patterns of Gender Development. Annual Review of Psychology, 61., 353-381.

Martin, C. L., Kornienko, O., Schaefer, D. R., Hanish, L. D., Fabes, R. A. és Goble, P. (2013): The Role of Sex of Peers and Gender-Typed Activities in Young Children's Peer Affiliative Networks: A Longitudinal Analysis of Selection and Influence. Child Development, 84. 3. sz., 921-937.

Miller, J. B. (1976): Toward a new psychology of women. Boston: Beacon Press, Chicago.

Miller, C., Lurye, L. E., Zosuls, K.M. és Ruble, D. N. (2009): Accessibility of gender stereotype domains: developmental and gender differences in children. Sex Roles, 60. 11-12. sz., 870-881.

Norfleet James, A. és Richards, H. C. (2003): Escaping stereotypes: Educational attitudes of male alumni of single-sex and coed schools. Psychology of Men \& Masculinity, 4. 2. sz., $136-148$.

Novotney, A. (2011): Coed verus single-sex ed. Does separating boys and girls improve their education? Experts on both sides of the issue weigh in. Monitor on Psychology, 42. 2. sz., 58.

Ólafsdóttir, M. P. (1996): Kids are both girls and boys in Iceland. Women's Studies International Forum, 19. 4. sz., 357-369.

Poulin-Dubois D, Serbin L. A. és Derbyshire, A. (1998): Toddlers' intermodal and verbal knowledge about gender. Merrill-Palmer Quarterly, 44., 338-354.

Powlishta, K. K. (1995): Intergroup processes in childhood: Social categorization and sex role development. Developmental Psychology, 31. 5. sz., 781-788. 
Quinn, P.C., Yahr, J., Kuhn, A., Slater, A. M, és Pascalis, O. (2002): Representation of the gender of human faces by infants: a preference for female. Perception, 31. 9. sz., 11091021.

Rédai Dorottya (2010): Veszélyes ideológiák az óvodában? Eduline, 2010. 08. 31. URL: http://eduline.hu/kozoktatas/2010/8/31/20100830_gender_nemi_sztereotipiak_ ovoda

Robinson, K. H. (2002): Making the Invisible Visible: gay and lesbian issues in early childhood education. Contemporary Issues in Early Childhood, 3. 3. sz., 415.

Ruble, D. N., Alvarez, J., Bachman, M., Cameron, J., Fuligni, A., et al. (2004): The development of a sense of self: the development and implications of children's collective identity. In: Bennett, M. és Sani, F. (eds.): The Development of the Social Self. Psychology Press, East Sussex, UK, 29-76.

Rudman, L. A. és Glick, P. (2008): The Social Psychology of Gender: How Power and Intimacy Shape Gender Relations. Guilford, New York.

Sandberg, A., és Pramling-Samuelsson, I. (2005): An Interview Study of Gender Differences in Preschool Teachers' Attitudes Toward Children's Play. Early Childhood Education Journal, 32. 5. Sz., 297-305.

Sax, L. (2006): Six Degrees of Separation: what teachers need to know about the emerging science of sex differences. Educational Horizons, Spring 2006, 190-200.

Sherlock, L. (2012): Sociopolitical influences on sexuality education in Sweden and Ireland. Sex Education: Sexuality, Society and Learning. 12. 4. sz., pp. 383-396.

Signorella, M. L., Bigler, R. S. és Liben, L. S. (1993): Developmental differences in children's gender schemata about others: a meta-analytic review. Developmental Review, 13. 2. sz., 147-183.

Trautner, H. M., Ruble, D. N., Cyphers, L., Kirsten, B., Behrendt, R. és Hartman, P. (2005): Rigidity and flexibility of gender stereotypes in children: developmental or differential? Infant and Child Development, 14. 4. sz., pp. 365-380.

Updegraff, K. A., McHale, S. M. és Crouter, A. C. (2000): Adolescents' Sex-Typed Friendship Experiences: Does Having a Sister versus a Brother Matter? Child Development, 71. 6. sz., 1597-1610.

Zosuls, K. M., Ruble, D.N., Tamis-LeMonda, C. S, Shrout, P. E, Bornstein, M. H. és Greulich, F. K. (2009): The acquisition of gender labels in infancy: implications for sex-typed play. Developmental Psychology, 45. 3. sz.,688-701. 